\title{
Factors that determine the price of game
}

\author{
P. Van Der Merwe, M. SaAyman and W. Krugell
}

Van der Merwe, P., M. Saayman and W. Krugell. 2004. Factors that determine the price of game. Koedoe 47(2): 105-113. Pretoria. ISSN 0075-6458.

Today, approximately 50 years after the first game farm was established in South Africa, the game industry has grown significantly, and is growing still. There are roughly 9000 game farms and they make a large contribution to both the tourism industry and nature conservation. The price of the majority of game species in South Africa shows an upward trend since 1990. Lately, a number of species, such as roan antelope, reedbuck, white springbok, black wildebeest, grey rhebuck and white rhinoceros have seen significant increases in value. The price increases can be attributed to a number of factors. The factors include the growth in the number of game farms, that in turn is driven by the growth of the tourism industry in South Africa, coupled with the growth of trophy hunting and increased demand for game meat products. Farmers have diversified into game farming in areas that are otherwise not suitable for cattle or crop farming. These increases in demand has, however, to some extent been met by the success of game breeding programmes (specifically of endangered and rare species). The question that comes to mind is which factors have the most significant impact on the price of game. Answers to this will help game farm owners to manage the fluctuation in game prices better. Based on the above the aim of this paper is to determine to what extent the abovementioned factors have an influence on the price of game and which factors have the most significant impact. Panel data consisting of the price of different game species, number of game farms, number of tourist arrivals and the number of trophies hunters were analysed for the years 1996-2001. A regression analysis is undertaken to identify the determinants of the price of game in South Africa. The above-mentioned factors explain the movement in the price of game, specifically that the demand factors have a significant influence on the price. Therefore an increase in the number of trophy and biltong hunters as well as demand for game farms impacts significantly on the price of game.

Keywords: game sales, game farm, nature conservation, ecotourism, game farm tourism, hunting.

P. Van der Merwe, M. Saayman and W. Krugell, North-West University, School for Entrepreneurship, Marketing and Tourism Management: Institute for Tourism and Leisure Studies and the School of Economics, Risk Management and International Trade, Private Bag X6001, Potchefstroom, 2520 Republic of South Africa. (ontpvdm@puk.ac.za).

\section{Introduction}

Fraser (1999) forecasts that South Africa's tourism industry will grow by more than $5.5 \%$ between 1998 and 2010, which is better than the predicted $4.1 \%$ for the global market. It is estimated that arrivals will increase from six million international tourists in 2000 to 30.5 million in 2020 (WTO 2001). The African continent can triple the size of its tourism industry by 2020 if proper efforts are made. This will result in forecast tourist arrivals of 77.3 million to Africa.

On the African continent, South Africa attracts the most overseas tourists, which makes tourism one of the largest industries in South Africa (WTO 2001). Research indicates that tourism contributes approximately $4.6 \%$ to the Gross Domestic Product (GDP). In 2002, tourism arrivals increased by $16 \%$, making South Africa one of the highest 


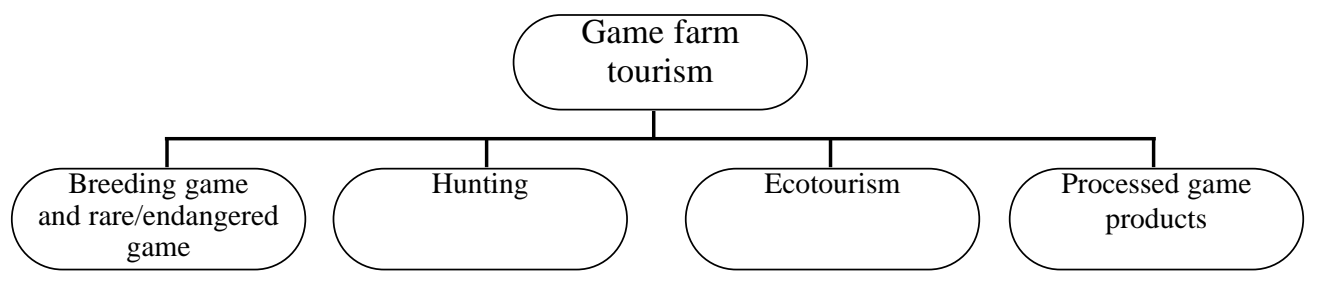

Fig. 1. Four pillars of game farm tourism.

growth destinations in the world (Thornton \& Feinstein 2002; GCIS 1998).

For both local and overseas tourists, scenic beauty and wildlife remain the major attractions (ecotourism) that South Africa has to offer (GCIS 1998; GCIS 1999). It is a fact that $80 \%$ of nature conservation in South Africa is taking place on privately-owned land, such as game farms (Eloff 2000; Fox \& Du Plessis 2000). Hence, an increase in the demand for game, and for sustainable management of game farms in all its facets. Game farm tourism, according to Van der Merwe \& Saayman (2001) is based on four pillars (Fig. 1). The pillar of interest for this paper is the first mentioned, namely, breeding game and rare/endangered game which includes game auctions/sales.

The reason for this is that researchers such as Furstenburg \& Van Niekerk (2004), Eloff (2004) and Du Plessis (2003) have indicated that a great number of aspects influence the price of game. In order for game farm owners to manage their game farms and specifically their stock (game) more effectively it has become important to know which factors are having the most significant impact on the price of game, for if the price of game drops or increases it has an impact on the profitability and viability of game farms.

The aim of this paper is to determine the factors that have the most significant impact on the price of game.

\section{Game farming in South Africa}

The size and scope of game farming in South Africa

In 2000 , it was estimated that there were approximately 7000 privately-owned game farms in South Africa, with a total surface area of 16 million ha (Ebedes 2002) of which 5061 farms are fenced according to Nature Conservation regulations. Research conducted in 1993 indicated that the surface area of exempted game farms constituted $8.5 \%$ of the total agricultural land in South Africa, which increased to $12.5 \%$ in 2000 , with a total of 1.7 million head of game (Eloff 2002; Erasmus 2000; CIC 2004). According to Bothma (2002) there was a $2.5 \%$ increase in land utilised for game farming from 1998 to 1999 . The latter translates into a 300000 ha per year increase for the purpose of gamefarm tourism. Flack (2002a) states that it is estimated that the conversion rate from cattle to game farming in 2002 was nearly 500000 ha, which is 200000 ha more than the 1998 to 1999 increase. Statistics of 2002 showed that $13.3 \%$ of the agricultural land was used for game farming, while national and provincial game reserves only covered $6 \%$ or 6.1 million ha of land in South Africa (Flack 2002a; Van der Walt 2002).

Over and above the fact that the 7000 game farms in South Africa during 2000 generated approximately R1 billion, game farms also employ approximately 63000 people (Van der Merwe \& Saayman 2003). Live game sales and the breeding of rare/endangered species is the second biggest generator of 
Table 1

Auction sales over the past ten years

\begin{tabular}{|c|c|c|c|c|}
\hline Year & $\begin{array}{l}\text { Number of } \\
\text { Game Sold }\end{array}$ & $\begin{array}{l}\text { \% Change } \\
\text { In Volume }\end{array}$ & $\begin{array}{c}\text { Turnover } \\
\text { In Rand } \\
\text { (Tax Excluded) }\end{array}$ & $\begin{array}{l}\text { \% Change } \\
\text { In Value }\end{array}$ \\
\hline 1991 & 8292 & & 8999871 & \\
\hline 1992 & 9546 & (+) $15 \%$ & 10059969 & (+) $20.66 \%$ \\
\hline 1993 & 11499 & (+) $19.93 \%$ & 11732596 & (+) $8.04 \%$ \\
\hline 1994 & 11096 & $(-) 3.08 \%$ & 11705605 & (-) $0.23 \%$ \\
\hline 1995 & 9171 & (-) $17.35 \%$ & 14335894 & (+) $22.47 \%$ \\
\hline 1996 & 11340 & $(+) 23.65 \%$ & 26559557 & $(+) 85.26 \%$ \\
\hline 1997 & 12077 & (+) $6.5 \%$ & 28526052 & (+) $7.4 \%$ \\
\hline 1998 & 14354 & (+) $18.85 \%$ & 40017964 & (+) $40.29 \%$ \\
\hline 1999 & 15455 & (+) $7.67 \%$ & 53705823 & (+) $34.2 \%$ \\
\hline 2000 & 17702 & (+) $14.54 \%$ & 62960451 & (+) $17.23 \%$ \\
\hline 2001 & 17282 & (-) $2.37 \%$ & 87000473 & (+) $38.18 \%$ \\
\hline 2002 & 20022 & (+) $15.85 \%$ & 105192180 & (+) $20.91 \%$ \\
\hline 2003 & 19645 & (-) $1.88 \%$ & 102420445 & (-) $2.63 \%$ \\
\hline
\end{tabular}

(Source: Eloff 2002, 2003, 2004)

revenue for game farm tourism and contributed approximately $30 \%$ of the total amount generated by game farms in South Africa. Eloff (1999) divided the breeding of game into two categories. Firstly, breeding common game species, such as kudu, springbok and impala. Secondly, breeding endangered and rare game species such as sable antelope, black rhino and roan antelope. In the two categories mentioned above the emphasis is on the production of game species to be auctioned to game farmers.

\section{Game auctions}

Analysis of game auctions from 1991 to 2001 reveals an average increase of $9 \%$ per year over an 11-year period. The turnover per year grew from almost R9 million in 1991 to R105 million in 2002, with an average growth rate of R38 million per year over 12 years (Table 1) (Eloff 2002; Eloff 2003; Eloff 2004).

Table 1 shows a steady increase in the numbers of game sold over the 13-year period from 1991 to 2003. The values, however, indicates a surge in average game prices with increases in turnover value of $85 \%$ in $1995 / 1996,40 \%$ in $1997 / 1998$ and $38 \%$ in
2000/2001. The volume of live game sold stabilised during the 2001 season but there was still an active and growing demand, especially for the rare game species. The more common species have recently shown signs of price maturity, but new record prices have also been set (Bothma 2002). In 2003, the value of sales was $2.63 \%$ less than in 2002, going down from R105 million to R102 million. Factors that contributed to this reduction were the drought that was experienced during the second part of the year in one of the leading provinces in game farm tourism, namely the Limpopo Province, and a general cost increase in South Africa.

Table 2 indicates the average increase or decrease in the price of the different game species over the past ten years.

Flack (2002b) indicates that in 1992, there were only nine auctions per year, with 9546 heads of game auctioned. This grew to 48 auctions in 2000 and 17702 heads of game sold. In 2002, this number increased to 20022 (Table 1). It decreased by $1.88 \%$ in 2003, with a total of 19645 heads of game sold at 59 auctions. Therefore, noticably, a significant increase in the number of auctions per year as well as in the price of game 
Table 2

Percentage price increase (+) or decrease (-) in average auctioned game prices over the past ten years

\begin{tabular}{|c|c|c|}
\hline $\begin{array}{r}\text { Ave } \\
\mathrm{P}\end{array}$ & $\begin{array}{l}\text { verage \% price } \\
\text { increase } \\
\text { per year in } \\
\text { ten years }\end{array}$ & $\begin{array}{c}\% \text { increase }(+) \\
\text { or decrease (-) } \\
\text { in } 2000 \text { compared } \\
\text { with } 1999\end{array}$ \\
\hline Roan antelope & $40.81 \%$ & (-) $8.2 \%$ \\
\hline Tsessebe & $21.08 \%$ & $(+) 49.25 \%$ \\
\hline Blesbok: White & $13.48 \%$ & (-) $19.50 \%$ \\
\hline Blesbok: Common & $15.04 \%$ & $(+) 3.84 \%$ \\
\hline Blue wildebeest & $19.92 \%$ & (-) $0.98 \%$ \\
\hline Bontebok & $21.59 \%$ & $(+) 15.9 \%$ \\
\hline Bushbuck & $28.49 \%$ & $(+) 23.92 \%$ \\
\hline Buffalo/disease free & $29.65 \%$ & $(+) 53.13 \%$ \\
\hline Duiker & $18.73 \%$ & $(+) 32.07 \%$ \\
\hline Eland/cape & $10.58 \%$ & $(+) 13.44 \%$ \\
\hline Gemsbok & $16.40 \%$ & $(+) 4.74 \%$ \\
\hline Giraffe & $9.10 \%$ & (+) $13.79 \%$ \\
\hline Klipspringer & $14.35 \%$ & (-) $6.45 \%$ \\
\hline Kudu & $142.51 \%$ & $(+) 16.11 \%$ \\
\hline Lion & $5.42 \%$ & (-) $54.86 \%$ \\
\hline Nyala & $210.32 \%$ & $(+) 80.33 \%$ \\
\hline Reedbuck & $49.23 \%$ & $(+) 49.65 \%$ \\
\hline Impala & $19.8 \%$ & $(+) 5.11 \%$ \\
\hline Red hartebeest & $15.72 \%$ & $(+) 8.74 \%$ \\
\hline Mountain reedbuck & $29.88 \%$ & (+) $22.14 \%$ \\
\hline Burchell's zebra & $8.18 \%$ & (+) $18.97 \%$ \\
\hline Springbok: Common & $22.37 \%$ & (-) $6.83 \%$ \\
\hline Springbok: Heartwater & $7.4 \%$ & $(+) 30.64 \%$ \\
\hline Springbok: Black & $20.3 \%$ & $(+) 13.47 \%$ \\
\hline Springbok: White & $38.44 \%$ & (+) $155.2 \%$ \\
\hline Steenbok & $22.34 \%$ & $(+) 53.61 \%$ \\
\hline Black rhinoceros & $5.31 \%$ & (+) $69.68 \%$ \\
\hline Black wildebeest & $49.98 \%$ & (+) $5.1 \%$ \\
\hline Sable antelope & $11.19 \%$ & $(+) 9.85 \%$ \\
\hline Fallow deer & $28.83 \%$ & $(+) 1.64 \%$ \\
\hline Grey rhebuck & $82.68 \%$ & (-) $12.72 \%$ \\
\hline Warthog & $11.24 \%$ & (-) $8.7 \%$ \\
\hline Ostrich & $10.58 \%$ & $(+) 39.46 \%$ \\
\hline Waterbuck & $12.00 \%$ & $(+) 36.5 \%$ \\
\hline White rhinoceros & $30.37 \%$ & (+) $39.67 \%$ \\
\hline Total game & $11.35 \%$ & (+) $14.54 \%$ \\
\hline Total turnover & $60.02 \%$ & (+) $17.23 \%$ \\
\hline
\end{tabular}

(Source: Eloff 2002)

in general. Hence, the question: what has been driving the boom in the price of game?

According to Table 2, the five game species that had the biggest average percentage price increase per year from 1991 to 2000 were the following; nyala (210.32\%), kudu (142.51\%), grey rhebuck
(82.68 \%), black wildebeest (49.98 \%) and reedbuck $(49.23 \%)$. The five game species that had the biggest increase in sales in 2000-2001 were as follows; tsessebe (60.9\%), springbok (31.2\%), sable antelope (24.2\%), nyala (20.2\%) and Burchell's zebra (13.9\%) (Eloff 2002).

\section{Determinants of the price of game}

The price of game is determined by factors that influence the demand for and supply of game. Microeconomics explains that price is determined by the interaction of demand and supply. This can be illustrated with a simple diagram. Figure 2(a) shows a negative relationship between price and the quantity demanded and a positive relationship between price and quantity supplied. The equilibrium price and quantity are set where the two curves intersect. Figure 2(b) abstracts from the situation in the South African game industry where there has been an increase in the equilibrium price and quantity over a number of years. This section examines the determinants of the price of game, by looking at the factors that could have caused the increases in demand and supply.

At the most basic level the increase in the demand for game stems from the growth in the number of game farms in South Africa, described in section 2 (ABSA 2003). A number of factors have played a role in the conversion of regular commercial farms into game farms. These major factors are the following:

- problems that traditional livestock/crop farming are currently experience makes it a good a option such as to compete with other countries that do receive subsidies from their governments; 
a

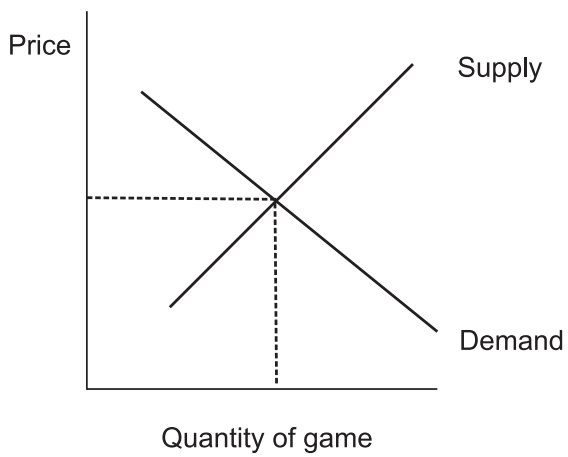

Fig. 2. Interaction of demand and supply

- the deregulation of the agricultural sector, resulting in lower, but also more competitive prices;

- $\quad$ an increase in the loss of livestock due to stock theft on farms;

- the control of cattle diseases had become an expensive operation;

- a decline in farmers' political power base in Parliament since the early 1990s;

- the number of land claims that increased;

- bush encroachment that increased (which often resulted from overgrasing which, in turn, reduced the frequency of veldfires);

- the impact of global warming (ABSA 2003; Eloff 2001; Van Zyl 2002; Du Plessis 2003; Van der Walt 2003; Schak 2003a; Smith 2004).

While there are drivers of growth there are also forces counteracting the growth of the demand for game. These include the following:

- political developments such as new legislation put forward by political parties can also influence the price of game, proposed translocation act, firearms control act (act 60 of 2000) firearms control aspects regarding overseas hunters and South Africa’s crime situation;

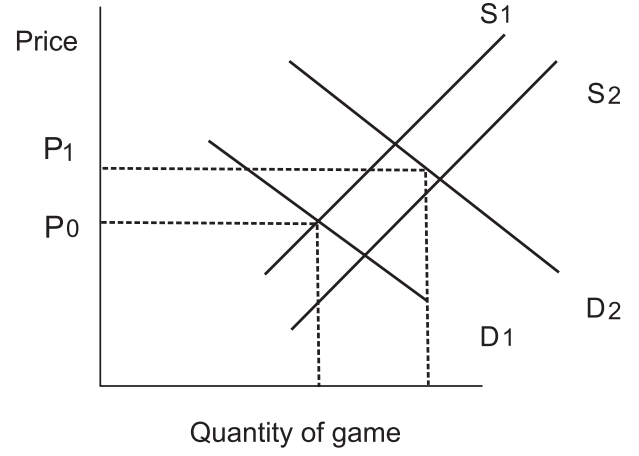

- economic developments, such as the distance that game need to be transported to market, a decrease in discretionary income, population growth and need for land, possible surplus of game in future, stronger rand hampering game meat exports and game capturing technique use to capture game;

- climate/weather conditions namely, drought and floods;

- the pressure against the consumptive use of wildlife;

- diseases such as foot-and-mouth, anthrax, tuberculosis, rinderpest, bovine malignant and African swine fever to mention a few (PHASA 2000; PHASA 2003; Du Toit et al. 2002; Thomson 2004; Schak; 2003b; Makhubela 2004; Furstenburg \& Van Niekerk 2004; Hamman et al. 2002; Eloff 2004; Damm 2004b; Damm 2004a; Damm 2004c; Scriven \& Eloff 2003; Neethling 2003).

While the higher prices discussed in the previous section reflects an increase in the demand for game, Table 1 also showed that the demand was to some extent met by increases in the supply. Table 1 showed a steady increase in the numbers of game sold over the period. The factors that have been influencing the supply-side of the market include factors such as: 
- The development of more game farms

- Climate/weather conditions namely good raining seasons

- The consumptive use of game such as biltong- and trophy hunting

- The success obtained in the breeding programmes of rare/endangered game

- Farmers today are more conservation orientated

- The economic value that lies in the breeding with game (Du Plessis 2003; Eloff 2001; KZN-Wildlife 2003; Van der Merwe \& Saayman 2001; Van Zyl 2002).

The following section undertakes econometric analysis of the determinants of the price of game.

\section{Empirical analysis}

The empirical analysis of the determinants of the price of game involves regressing the average price on a number of explanatory variables. The estimating equation can be expressed as follows:

$p_{i t}=c+\beta q_{i t}+\varepsilon_{i t}$

Where $p_{i t}$ is the average price of specie $i$ in year $t$. The intercept, or constant term, is represented by $c$. The $q_{i t}$ represents a vector of determinants of the price of game (where $\beta$ denotes the coefficients). Unfortunately, data constraints limit the variables that can be included here. Many of the determinants discussed in the previous section are particularly difficult to quantify such as drought or good rainy seasons, new legislation and diseases. There is a lack in good research in the game farm tourism industry such as how many biltong hunters hunt per year and how much do they spend to mention only a few. The explanatory variables that can be included are: the quantity of game, the number of game farms in the country, the number of tourists visiting South Africa, as well as the number of trophy hunters. Following the law of demand one could expect a negative relationship between price and quantity. The numbers of game farms, visiting tourists and trophy hunters are expected to be positively related to the price of game. The error term $(\varepsilon)$ captures the effects of unmeasured attributes that affect the price of game.

A panel data set is used to estimate the regression equation. It contains data on the prices and quantities of 43 species of game sold at auction over the period 1996 to 2003. The list of species is included in the appendix. Data on the number of game farms, number of tourists and trophy hunters are obtained from PHASA (Professional Hunters Association of South Africa, South Africa Tourism and The Centre for Wildlife Economics at North-West University. Where possible natural logs were taken. Regressions were estimated using Stata 8 software.

The estimation strategy involves estimating levels and growth rates versions of the estimating equation, using a panel data random effects estimator. The estimator is a weighted average of the between estimator that uses the variation between cross-section observations (in other words, between species), and the within estimator that uses the time variation within each cross-section of observations.

Table 3 shows the results for the levels and growth rates specifications. In the levels specifications the numbers of farms, tourists and trophy hunters explain the price level. The levels model (2) provides the best results. As expected, there is a negative and significant relationship between the price level and the quantity of game sold at auctions. There is a positive relationship between the price of game and the number of game farms and the number of trophy hunters. The results are similar to that of levels model (1) where the numbers of tourists, rather than the number of trophy hunters, are used, but it has a slightly better overall fit. Including both the numbers of tourists and the numbers of trophy hunters as explanatory variables, as is done in the levels model (3), causes the tourists variable to become insignificant. Overall, it is clear though that the models have low explanatory power. The levels model (2) has an overall $\mathrm{R}^{2}$ of 0.13 , 
Table 3

Estimation results

\begin{tabular}{lcccccc}
\hline Variable & $\begin{array}{c}\text { Levels } \\
\text { model (1) }\end{array}$ & $\begin{array}{c}\text { Levels } \\
\text { model (2) }\end{array}$ & $\begin{array}{c}\text { Levels } \\
\text { model (3) }\end{array}$ & $\begin{array}{c}\text { Growth } \\
\text { rates (4) }\end{array}$ & $\begin{array}{c}\text { Growth } \\
\text { rates (5) }\end{array}$ & $\begin{array}{c}\text { Growth } \\
\text { rates (6) }\end{array}$ \\
\hline Game sold & -0.036 & -0.092 & -0.090 & -0.005 & -0.007 & -0.007 \\
& $(-1.24)$ & $(-2.32)^{*}$ & $(-2.30)^{*}$ & $(-2.18)^{*}$ & $(-2.69)^{*}$ & $(-2.64)^{*}$ \\
Number of & 0.540 & 1.115 & 0.844 & 0.649 & 1.291 & 1.046 \\
game farms & $(3.47)^{*}$ & $(11.35)^{*}$ & $(4.37)^{*}$ & $(3.73)^{*}$ & $(11.95)^{*}$ & $(4.88)^{*}$ \\
Tourists & 1.445 & & 0.790 & 4.857 & & 2.281 \\
& $(3.89)^{*}$ & & $(1.63)$ & $(3.67)^{*}$ & & $(1.32)$ \\
Trophy & 0.413 & 0.286 & & 0.435 & 0.323 & \\
hunters & & $(4.71)^{*}$ & $(2.45)^{*}$ & & $(4.58)^{*}$ & $(2.54)^{*}$ \\
$\mathrm{R}^{2}$ & & & & & & \\
\multicolumn{1}{c}{ Within } & 0.49 & 0.55 & 0.56 & 0.48 & 0.55 & 0.56 \\
$\quad$ Between & 0.11 & 0.20 & 0.20 & 0.07 & 0.10 & 0.10 \\
\multicolumn{1}{c}{ Overall } & 0.07 & 0.13 & 0.14 & 0.08 & 0.09 & 0.10 \\
\hline
\end{tabular}

(* significant at a $5 \%$ level)

indicating that the conditioning variables explain 13 per cent of the variation in the price level over time and between species. This implies that the other determinants of game prices that are more difficult to quantify, also have a significant influence on the price level for example drought, change in legislation and diseases. The 'within' $\mathrm{R}^{2}$ is encouraging in this regard. For example, level model (2) does explain $55 \%$ of the 'within' (in other words, across time) variation.

The growth rate specifications explain the changes in the price of game in terms of changes in the numbers of farms, tourists and trophy hunters. The models yield largely similar results regarding the signs and significance of coefficients and the overall explanatory power of the model. The benefit of also running the growth rates estimations is that one can interpret the coefficients. For example, the growth rates level model (5) indicates that $12 \%$ increase in the number of game farms in the country will lead to a $10 \%$ increase in the price of game. Similarly, a four per cent increase in the number of trophy hunters will lead to a $10 \%$ increase in the price of game.

\section{Implications for game farms}

In South Africa where there is a growing demand for land, one can only foresee that a saturation point will be reached in terms of the availability for new developments and this will have an impact on the price of game species (Van der Merwe \& Saayman 2002). Therefore game farm owners have to think of alternative methods that will sustain game prices in the long run. Alternative methods include. Firstly, to start a marketing campaign in order to increase South Africa's market share of trophy hunting, because hunting is a consumptive form of usage. If one can increase the number of overseas trophy hunters one will also increase the demand in game. Secondly, a similar process need to be followed with biltong hunting, if one is able to increase the number of biltong hunters then there will also be an increase in the demand for game. Thirdly, the game industry need to position itself better as a supplier of game meat (venison) which will imply finding more and bigger markets. These methods can help to sustain a particular level of pricing. 


\section{Conclusion}

The aim of this paper was to determine the factors that have the most significant impact on the price of game. It is clear from the paper that game sales had increased over the last twelve years from nine auctions per year (1992) and 9546 game auctioned, to 59 auctions and 19645 game auctioned in 2003. The five game species that had the biggest average percentage price increase per year from 1991 to 2000 were the following; nyala (210.32\%), kudu (142.51\%), grey rhebuck (82.68\%), black wildebeest (49.98\%) and reedbuck (49.23\%). The literature also indicated that ecotourism and trophy hunting did become a booming industry in South Africa. A number of factors were identified that influence the price of game, viz., a decrease in the development of game farms; drought, or on the other hand, a good raining season; political instability; the rand/dollar exchange rate; and the proposed translocation act. Empirical analysis of the determinants of the price of game showed that the number of game farms, tourists and trophy hunters are significant explanatory variables. Trophy hunting has been identified as an important determinant of game prices.

These factors have an impact on the price of game and the demand for game is important, since a decrease in these industries can harm the game selling industry significantly.

\section{References}

ABSA. 2003. Report: Game ranch profitability in South Africa. Johannesburg: SA Financial Sector Forum.

Bothma, J. DU P. 2002. Some economics of wildlife ranching. Pp. 23-29. In: PENZHORN, B.L. (ed.). Game ranch planning and management. Symposium held at Onderstepoort, Pretoria on 1-2 Nov. 2002. Pretoria: Wildlife Group of the South African Veterinary Association.

Cic (InTERnational Council for Game AND Wildlife Conservation). 2004. Tourism and development: the win-win performance. Africa Indaba 2(2): 2.

DAmM, G.R. 2004a. Editor's comment. Africa Indaba 2(2): 1 .
DAMM, G.R. 2004b. IUCN welcomes adoption of sustainable use principles by CBD. Africa Indaba 2(2): 2-4.

DAMM, G.R. 2004c. Sustainable Lion Hunting. Africa Indaba 2(2): 14-15.

Du Plessis, P. 2003. Gevaarseine. Wild \& Jag 9(7):1.

Du Toit, J.G., B.L. Penzhorn \& J. Van Heerden. 2002. Bacterial, viral and protozoal diseases. Pp. 295-330. In: BотнмA, J. DU P. (ed.). Game ranch management. 4th edition. Pretoria: Van Schaik.

Ebedes, H. 2002. Preface. Pp. 7-9. In: Ebedes, H., B. Reilly, W. van Hoven \& B. Penzhorn (eds.). Sustainable utilization-conservation in practice. Proceedings of the $5^{\text {th }}$ International wildlife ranching symposium held at Pretoria on 20-23 March 2001. Pretoria: South African Game Ranchers Association.

ElofF, T. 1999. Wins uit wildboerdery. SA Wild \& Jag 5(2): 22-25.

ElofF, T. 2000. Die omvang van die wildbedryf in Suid-Afrika. Potchefstroomse Universiteit vir CHO. Ongepubliseerde verslag.

ElofF, T. 2001. Knelpunte en geleenthede. SA Game \& Hunt 2(5): 9.

Eloff, T. 2002. The economic realities of the game industry in South Africa. Pp. 78-86. In: EBEDES, H., B. Reilly, W. van Hoven \& B. Penzhorn (eds.). Sustainable utilization-conservation in practice. Proceedings of the $5^{\text {th }}$ International wildlife ranching symposium held at Pretoria on 20-23 March 2001. Pretoria: South African Game Ranchers Association.

ElofF, T. 2003. Gemiddelde wildveilingpryse 2002. SA Wild \& Jag 9(2): 21.

ElofF, T. 2004. Game sales 2003 in South Africa. Africa Indaba 2(2): 5.

ERAsmus, S.D. 2000. Die ekonomiese lewensvatbaarheid van ' $n$ wildvleisbewerkingsaanleg in Suid-Afrika. M.Com. verhandeling. Potchefstroomse Universiteit vir CHO.

FLACK, P.H. 2002a. The conservation revolution. SA Game \& Hunt 8(10): 29-33.

FlaCK, P. H. 2002b. Exotic game-catching up with Texas? Magnum (Oct.): 76-80.

Fox, T. \& P. DU Plessis. 2000. Hunting in Southern Africa. Africa Indigo 3(3): 40-47.

Fraser, J. 1999. Tourism is worth R80,6bn to SA. The Star (Aug. 17): 6.

Furstenburg, D. \& P. VAN NieKerK. 2004. Die wildbedryf en die voorgestelde wildhervestigingswet. SA Wild \& Jag 10(6): 30-31. 
GCis (GOVERnMENT COMMUNiCATION AND INFORMATION System). 1998. South Africa Official Yearbook. Cape Town: Rustica.

GCIS (GOVERNMENT COMMUNICATION AND INFORMATION SySTEM). 1999. South Africa Official Yearbook. Cape Town: Rustica.

Hamman, K. H. Stadler \& P. Lloyd. 2002. Is die wildbedryf versoenbaar met natuurbewaring? SA Wild \& Jag 9(4): 35-36.

KzN-WiLdLIFE. 2003. Game auctions. SA Game \& Hunt 9(8): 21-23.

Makhubela, W. 2004. Firearms Control Act South Africa. Africa Indaba 2(2): 5.

Neethling, P. 2003. Sterk rand knel wildvleisuitvoer. SA Wild \& Jag 9(7): 53.

Phasa (Professional Hunters Association of South AfricA). 2000. Professional Hunters Association of South Africa. Statistics. Pretoria: PHASA.

Phasa (Professional Hunters Associations of South Africa) 2003. Professional Hunters Association of South Africa. Statistics. Pretoria: PHASA.

SCHAK, W. 2003a. Brusellos. SA Wild \& Jag 9(10): 24-25.

SCHAK, W. 2003b. Bek-en-klouseer. SA Wild \& Jag 9(5): 24-25.

SCRIVEN, L. \& T. Eloff. 2003. Markets derived from nature tourism in South Africa and KwaZuluNatal. Pp. 247-324. In: AYLWARD, B. \& E. LuTz (eds.). Nature tourism, conservation, and development in KwaZulu-Natal, South Africa. Washington, DC: World Bank Publishers.

Smith, C. 2004. Wild behaal rekordpryse op Rooikraal-wildveiling. Volksblad, Mrt. 27: 3.
Thomson, R. 2004. National parks in crisis? Africa Indaba 2(2):16.

Thornton, G. \& K. Feinstein. 2002. Tourism talk: a summery of the most important data and statistics relevant to the regional tourism industry. The Journal of Southern Africa Tourism 1(3): 48-53.

VAn Der Merwe, P. \& M. SAayman. 2001. Managing game farms from a tourism perspective. Potchefstroom: Ons Drukkers.

VAn Der Merwe, P. \& M. SaAyman. 2002. A different approach to wildlife tourism and hunting. Pp. 128-136. In: EBedes, H., B. ReIlly, W. vaN Hoven \& B. Penzhorn (eds.). Sustainable utilization-conservation in practice. Proceedings of the $5^{\text {th }}$ International wildlife ranching symposium held at Pretoria on 20-23 March 2001. Pretoria: South African Game Ranchers Association.

Van Der Merwe, P. \& M. SaAyman. 2003. Determining the economic value of game farm tourism. (Paper delivered at the 55th International Atlantic Economic Conference at Vienna Austria on 13-16 March 2003.) Vienna. (Unpublished.)

Van der Walt, J. 2002. Proliferation of game ranches. SA Game \& Hunt 8(10): 7.

Van der Walt, J. 2003. Malignant catarrhal fever. SA Game \& Hunt 9(8): 7.

Van Zyl, J. 2002. Wees mak as jy jou somme maak. Finansies en tegniek Mrt: 22.

World TOURISM ORganisation (WTO). 2001. Africa to triple tourist numbers. [Web:] http://www.world-tourism.org/newsroom /releases/more_releases/R010607.html [Date of access: 19 March 1999]. 